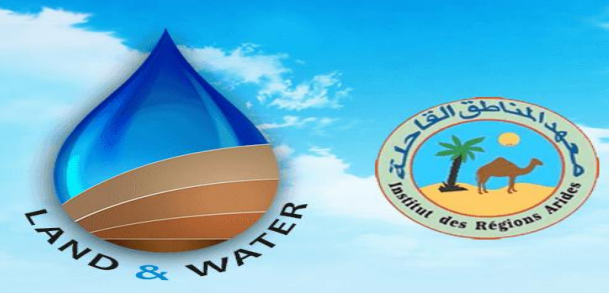

THE INTERNATIONAL CONFERENCE ON ' INTEGRATED LAND AND WATER RESOURCES MANAGEMENT IN THE DRY AREAS UNDER CLIMATE CHANGE'

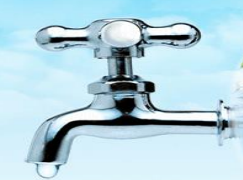

Q.

\title{
How Investment in RD\&E Offset the Negative Impact of Climate Change on the Tunisian Agricultural Productivity Sector
}

Boubaker Dhehibi, Aymen Frija and Aden Aw-Hassan SEPRP/ICARDA/AMMAN-JORDAN b.dhehibi@cgiar.org
Djerba, Tunisia| 15/05/2015 


\section{Introduction and Objectives}

- The role of TFP growth in accelerating and sustaining the pace of agricultural growth is widely recognized

- This is especially relevant for countries suffering from wide yield gaps, and increasing growing population and climate change pressures

- Agricultural productivity growth may face several challenges including natural (climate), socioeconomic (knowledge and skills) and institutional (incentives) constraints 


\section{Introduction and Objectives}

- This problem is mainly relevant for the MENA countries (Tunisian case)

- Food insecurity in this country is a recurring challenge related to several critical factors including climate change, scarcity of water and limited area for agricultural production

- Agriculture in the country is highly climate-sensitive

- A large share of population and economic activities in the country are located in urban coastal zones, which partly disconnect the farming activities from other economic sectors 


\section{Introduction and Objectives}

- By 2050 water availability per capita will fall by 50 percent, (Warren et al. 2006)

- Growing competition for water is expected to reduce the share of agriculture in total GDP to 50 percent by 2050

- A high potential for food crises due to increasing demand (population) and declining supply factors (precipitation and yields)

- A need to focus on food production inefficiencies and work on enhancing the productivity of the agricultural sector 


\section{Introduction and Objectives}

- Importance of analysing the agricultural productivity at the global scale and investigate the potential policies and macro-variables affecting this productivity

- The Overall objective of this study is to analyse the agricultural productivity of the agricultural sector in Tunisia and its main determinants, particularly:

$\checkmark$ The magnitude and sustainability of the agricultural productivity (TFP) growth over the last four decades

$\checkmark$ Sources of the TFP growth

$\checkmark$ The role of different types of agricultural investments on the TFP growth (Investment in RD\&E)

$\checkmark$ The impact of climate change (measured in terms of change in rainfall) 


\section{Overview of the Tunisian Agriculture}

- 4 bioclimatic stages: the humid, subhumid, sub-arid, and arid

- Average annual rainfall all over the country is estimated at $207 \mathrm{~mm} /$ year

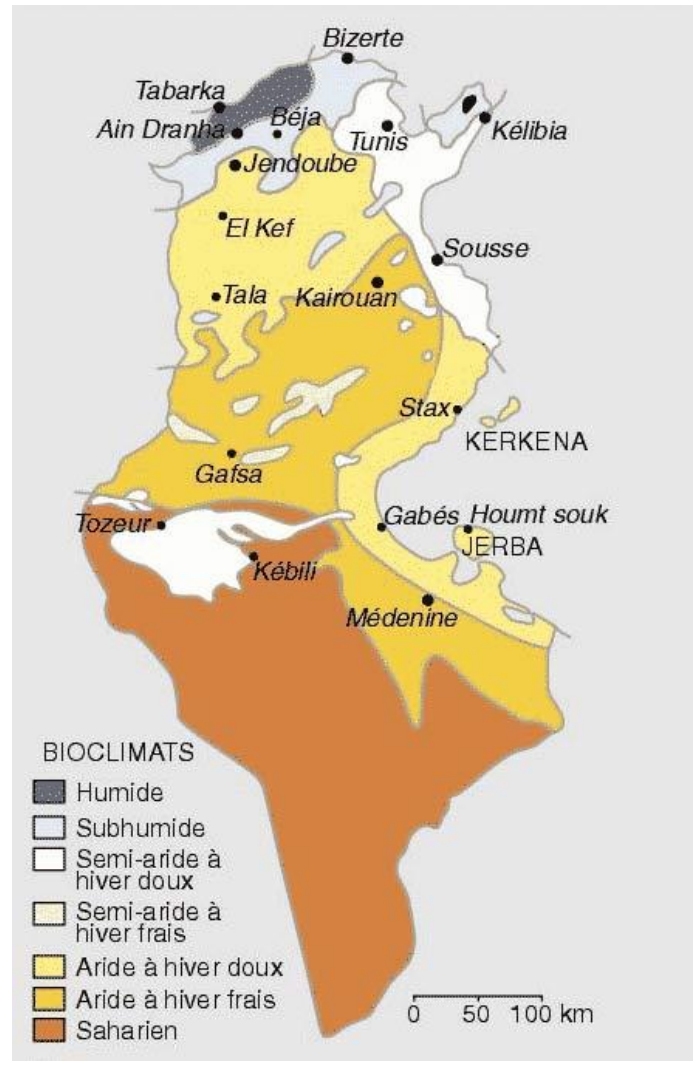




\section{Overview of the Tunisian Agriculture}

- The annual rain is highly variable among regions, with a value of $600 \mathrm{~mm}$ in the North of the country, $296 \mathrm{~mm}$ in the center, and $156 \mathrm{~mm}$ in the arid Southern region

- Almost $80 \%$ of the annual precipitation is usually falling between October and Marsh

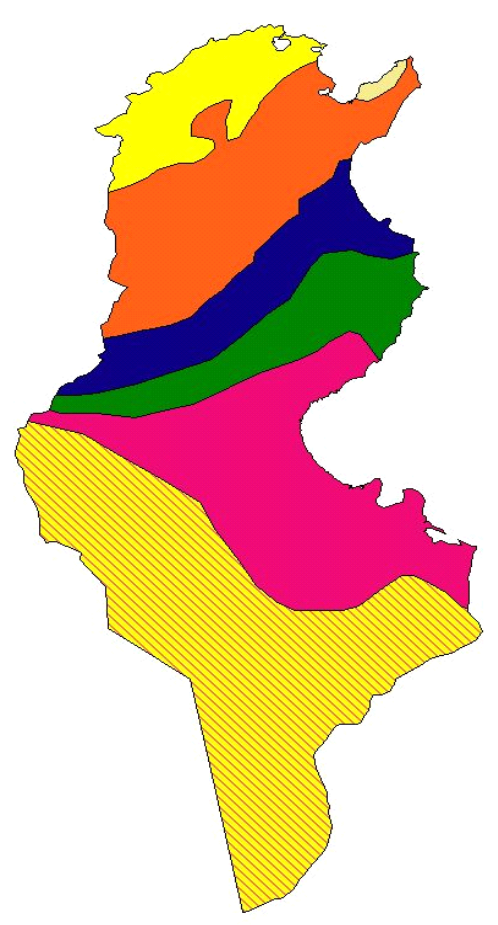

More than $500 \mathrm{~mm}$ $400 \mathrm{~mm}$ to $500 \mathrm{~mm}$ $300 \mathrm{~mm}$ to $400 \mathrm{~mm}$ $200 \mathrm{~mm}$ to $300 \mathrm{~mm}$ $100 \mathrm{~mm}$ to $200 \mathrm{~mm}$ Less than $100 \mathrm{~mm}$ 


\section{Overview of the Tunisian Agriculture}

Main characteristics of the Tunisian population

Source: National Statistics Institute (INS), 2012

\begin{tabular}{|l|c|c|c|c|c|}
\hline & 2008 & 2009 & 2010 & 2011 & 2012 \\
\hline Total population (1000 persons) & 10328.9 & 10439.6 & 10547.1 & 10673.8 & 10777. \\
\hline Males in the total population (\%) & 50.0 & 50.0 & 49.9 & 49.8 & - \\
\hline Urban population (\%) & 65.8 & 65.9 & 66.1 & 66.2 & 66.3 \\
\hline Population density per km $\mathbf{~}^{2}$ & 66.3 & 67.0 & 67.7 & 68.9 & - \\
\hline Number of households (1000 ) & 2407.2 & 2474.6 & 2539.1 & 2605.6 & - \\
\hline
\end{tabular}




\section{Overview of the Tunisian Agriculture}

- $11.5 \%$ to the national GDP

- Agricultural investments represent $10 \%$ of the total investments in Tunisia and $21 \%$ of the agricultural GDP

- $57 \%$ of these investments are done by private sector while $43 \%$ are public

- $17.6 \%$ of the total active population in 2010

- $11 \%$ to the total export at the same year
Percentage of employment contribution of different economic sectors Source: Central Bank of Tunisia, 2012

\begin{tabular}{|l|r|r|r|r|r|}
\hline & 1975 & 1984 & 1994 & 2004 & 2010 \\
\hline Agriculture & 36.5 & 27.3 & 21.2 & 16.2 & 17.6 \\
\hline Manufacturing industries & 17.6 & 19.7 & 19.6 & 19.4 & 18.3 \\
\hline Non-manufacturing industries & 12.6 & 15.8 & 13.7 & 14.5 & 14.4 \\
\hline Services & 29.7 & 35.2 & 43.9 & 48.9 & 48.8 \\
\hline
\end{tabular}

Importance of the agriculture in the national economy Source: ONAGRI, 2012

\begin{tabular}{|l|r|r|}
\hline Year & Added value (Million TND) & \% of the total GDP \\
\hline 2000 & 2383 & 13.8 \\
\hline 2002 & 2001 & 10.9 \\
\hline 2003 & 2432 & 12.6 \\
\hline 2004 & 2664 & 13.0 \\
\hline 2005 & 2478 & 11.6 \\
\hline 2006 & 2565 & 11.4 \\
\hline 2007 & 2650 & 11.1 \\
\hline 2008 & 2634 & 10.34 \\
\hline 2009 & 2847 & 11.67 \\
\hline Average & 2489 & 11.42 \\
\hline
\end{tabular}




\section{Overview of the Tunisian Agriculture}

- The area cultivated with permanent crops is only around $22 \%$ of the total agricultural area

- Water resources in the country are estimated to be around $4700 \mathrm{Mm} 3$

- 27 large dams, 182 hill dams and 698 artificial lakes

- Groundwater resources for around $43 \%$ of the total water potential

- Irrigated area represents only 8\% of the total agricultural surface

- They provide however $35 \%$ of the agricultural output value, $20 \%$ of total agricultural exports and $27 \%$ of agricultural employment
Distribution of the agricultural area in Tunisia (in Km2) Source: INS, 2012

\begin{tabular}{l} 
Unit : $\mathrm{Km}^{2}\left(1 \mathrm{~km}^{2}=100 \mathrm{ha}\right)$ \\
\hline Total Agricultural areas (a) \\
\hline Cropland (b) \\
\hline Permanent crops areas (c ) \\
\hline Rangelands \\
\hline Forests \\
\hline Others \\
\hline (c/a)*100 \\
\hline (c/b)*100
\end{tabular}

Water infrastructure in Tunisia/ Source: Plan Bleu, 2006 (cited in (GTZ, 2008))

\begin{tabular}{|l|r|r|r|r|}
\hline & & 2005 & 2010 & 2015 \\
\hline Large Dams & 27 & 42 & 49 \\
\hline Earth-fill dams & 220 & 255 & 275 \\
\hline Small lakes & & 800 & 1400 & 1660 \\
\hline Mobilized resources & & 2200 & 2400 & 2500 \\
\hline $\begin{array}{l}\text { Total mobilized resources compared to total } \\
\text { exploitable resources }\end{array}$ & & $88 \%$ & $96 \%$ & $100 \%$ \\
\hline
\end{tabular}




\section{Overview of the Tunisian Agriculture}

- 20000 ha are lost each year because of erosion

- Groundwater aquifers are overused in more than $25 \%$ of the irrigated areas

- The intensification rate in some irrigated areas is still below the targeted potentials

- Problems of social organization

- Small average size of the farms (most farms in Tunisia are smaller than $10 \mathrm{ha}$ ), and the continuous land fragmentation

... To this we have to add other problems specific to the rain fed Agriculture

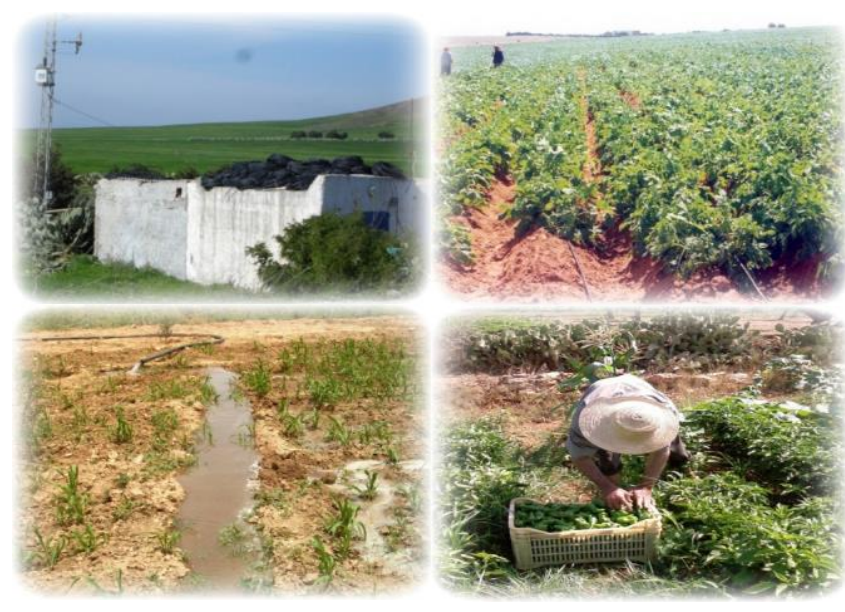
phenomenon 
Overview of the Tunisian Agriculture

- Highly dependent to climate variation,

- Low profitability, ...

- Negative national food balance, importations bills are usually depending on the climate conditions of the year,

- Weak and lowly performing value chains for the rain fed commodities

- Low and decreasing contribution to the national export,

- Low investment (public \& private) in RD\&E
Problems of the rain fed agriculture in

Tunisia
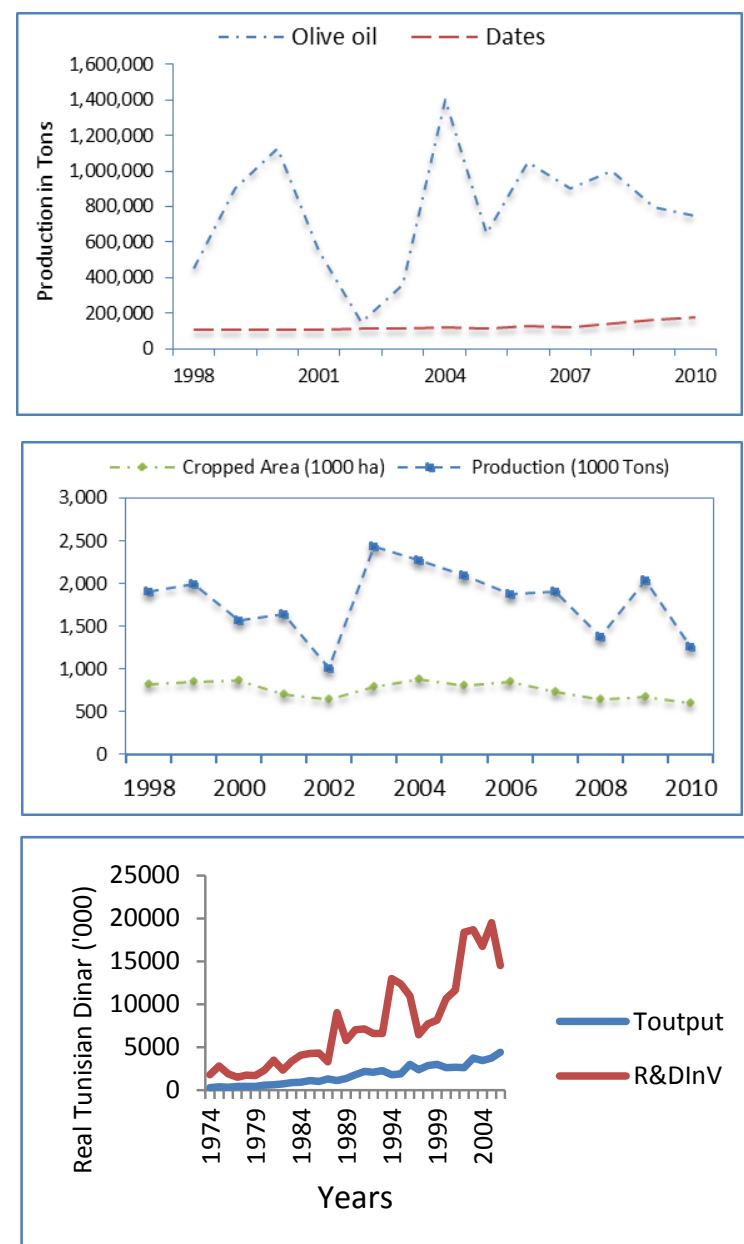


\section{Methodological Framework}

- Tornqvist indexes: used to construct both the aggregate output and input indexes

- Tornqvist can be used to divide the "technical change" into output and inputs changes

- Which are the main components for assessing the TFP growth 


\section{Methodological Framework}

Output index: $\operatorname{Ln}\left(\frac{Q_{t}}{Q_{t-1}}\right)=1 / 2 \frac{\sum_{j}\left(R_{j, t}+R_{j, t-1}\right)}{2\left(\frac{Q_{j, t}}{Q_{j, t-1}}\right)}$

Input index: $\quad \operatorname{Ln}\left(\frac{X_{t}}{X_{t-1}}\right)=1 / 2 \sum_{i}\left(S_{i, t}+S_{i, t-1}\right) \operatorname{Ln}\left(\frac{X_{i, t}}{X_{i, t-1}}\right)$

TFPG index: $\quad \operatorname{Ln}\left(\frac{T F P_{t}}{T F P_{t-1}}\right)=\operatorname{Ln}\left(\frac{Q_{t}}{Q_{t}}\right)=\operatorname{Ln}\left(\frac{X_{t}}{X_{t}}\right)$

Where;

$R_{j, t}$ is the share of output $(j)$ in total revenue in time (t),

$Q_{j, t}$ is the output (j) in time $(t)$,

$S_{i, t}$ is the share of input (i) in total input cost, and

$X_{i, t}$ is the input (i) in time $(t)$, 


\section{Methodological Framework}

- The TFP growth scores will be regressed on a set of variables:

$$
\begin{gathered}
T F P G=f(R D E, R F T N, R F T C, R F T S, \\
B T D, R R, T O, I N F)
\end{gathered}
$$




\section{Methodological Framework}

$$
T F P G=f(R D E, R F T N, R F T C, R F T S, B T D, R R, T O, I N F)
$$

\begin{tabular}{|c|c|c|}
\hline Variable & Description & ES \\
\hline RDE & Annual stock of RD\&E expenditure in the Tunisian Agricultural sector (TND) & + \\
\hline RFTN & Annual mean rainfall in the North of Tunisia ( $\mathrm{mm}$ ) & + \\
\hline RFTC & Annual mean rainfall in the Center of Tunisia $(\mathrm{mm})$ & + \\
\hline RFTS & Annual mean rainfall in the South of Tunisia $(\mathrm{mm})$ & + \\
\hline BTD & $\begin{array}{l}\text { Balanced territorial development Indicators (Annual rural GDP per capita expressed in } \\
\text { current TND/Capita/Year) }\end{array}$ & + \\
\hline $\mathbf{R R}$ & Resources reallocation: (share of annual agricultural employment) & + \\
\hline TO & $\begin{array}{l}\text { Trade Openness }(\%)=\text { (agricultural Import }+ \text { agricultural export }) /(\text { total agricultural } \\
\text { production). }\end{array}$ & + \\
\hline INF & Infrastructure: Road density (km / km2 agricultural land) & + \\
\hline
\end{tabular}




\section{Methodological Framework}

$$
T F P G=f(R D E, R F T N, R F T C, R F T S, B T D, R R, T O, I N F)
$$

- The log-linear form was considered as functional form

- The log-linear form allows for estimating coefficients that can be directly interpreted as elasticities

- In addition, the log-linear form contains a weak residual variance relative to other functional forms for the same data set and adjusts the data better than the linear specification for both forecasted parameter signs and statistical significance

- Period of analysis T: $1970-2011$ 


\section{Data Sources}

- The data used in this study was collected from different sources.

- FAO's annual time series (from 1961 to 2012....1970-2011) are used to construct the Törnqvist index:

$\checkmark \quad$ Tunisian agricultural (crops and livestock) production; Total cultivated area; Total labor employed in the agricultural sector; Machinery deployed in the agricultural activities; Animal capital, and Fertilizer consumption ....

- The FAO data is complemented, when needed, with data from national statistical agencies, especially when such alternative data is more accurate or up to date.

- Climate data: Tunisian National Meteorological Institute 


\section{Empirical Findings}

\begin{tabular}{|l|c|c|c|}
\hline & $\begin{array}{c}\text { Normalized Output } \\
\text { Index }\end{array}$ & $\begin{array}{c}\text { Normalized Input } \\
\text { Index }\end{array}$ & $\begin{array}{c}\text { Normalized TFPG } \\
\text { Index }\end{array}$ \\
\hline 1966 & 100 & 100 & 100 \\
\hline 1970 & 107.70 & 115.31 & 93.41 \\
\hline 1975 & 165.57 & 124.31 & 133.19 \\
\hline 1980 & 196.64 & 128.06 & 153.56 \\
\hline 1985 & 265.10 & 138.11 & 191.95 \\
\hline 1990 & 285.15 & 148.02 & 192.65 \\
\hline 1995 & 238.66 & 149.09 & 160.08 \\
\hline 2000 & 324.07 & 157.18 & 206.18 \\
\hline 2005 & 404.77 & 177.73 & 227.74 \\
\hline 2010 & 403.90 & 184.40 & 219.04 \\
\hline 2011 & 444.42 & 176.24 & 252.16 \\
\hline
\end{tabular}




\section{Empirical Findings}

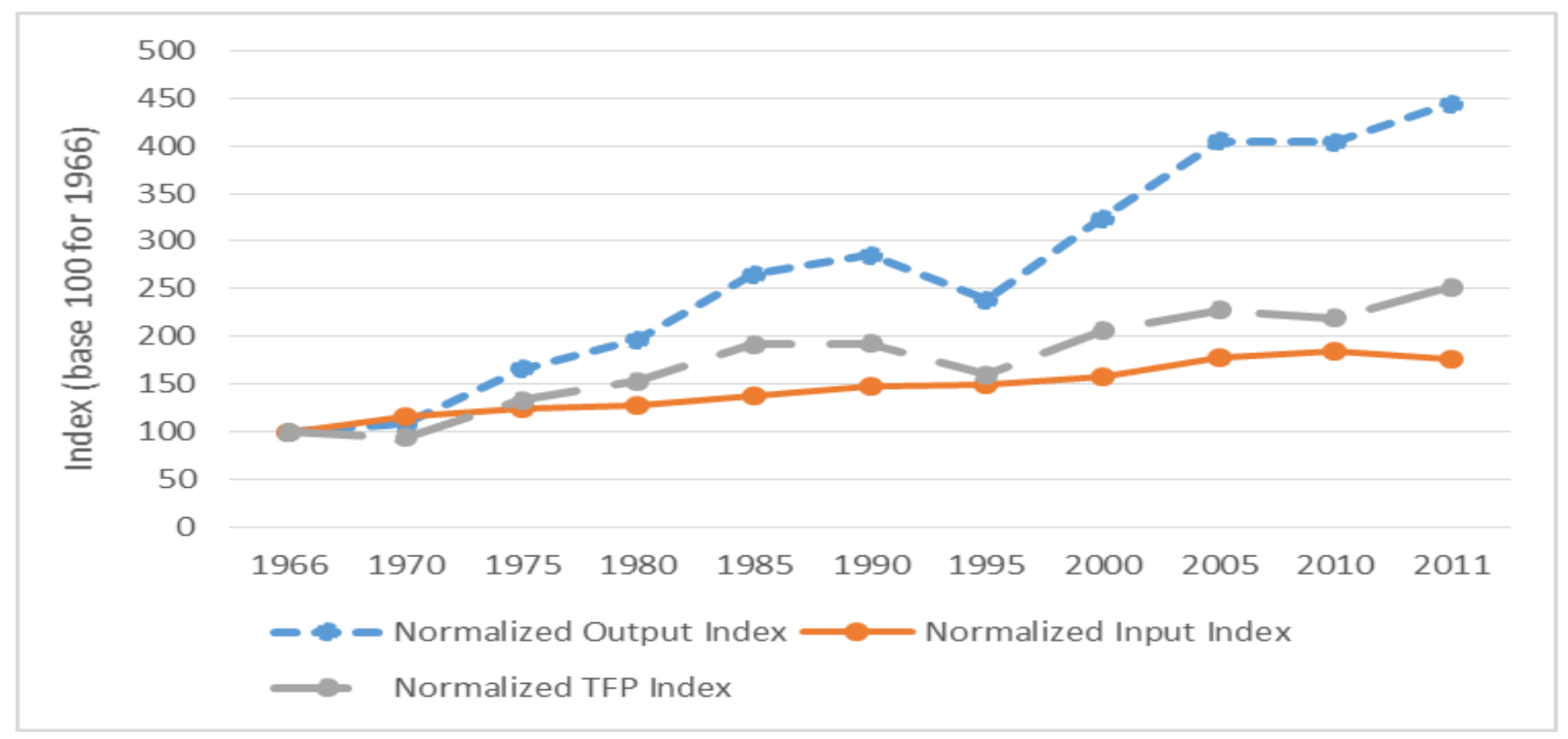

Trends of the output, inputs, and TFPG indexes (base 100 for 1966) 


\section{Empirical Findings}

\begin{tabular}{|c|c|c|c|}
\hline \multirow[b]{2}{*}{ Parameters } & \multicolumn{3}{|c|}{ Dependent variable $\operatorname{LnTFPG}_{t}$} \\
\hline & Estimated coefficients & t-ratios & $p$-value \\
\hline Constant & 0.915 & $2.43^{* *}$ & 0.021 \\
\hline $\mathrm{RDE}_{\mathrm{t}}$ & 0.05 & $1.44^{* * *}$ & 0.141 \\
\hline $\operatorname{RFTN}_{t}$ & 0.21 & $1.63^{* * *}$ & 0.113 \\
\hline $\operatorname{RFTC}_{t}$ & -0.109 & -0.835 & 0.410 \\
\hline $\mathrm{RFTS}_{\mathrm{t}}$ & 0.054 & 0.347 & 0.731 \\
\hline BTD $_{t}$ & 0.037 & 0.309 & 0.759 \\
\hline $\mathrm{RR}_{\mathrm{t}}$ & 0.05 & 0.213 & 0.833 \\
\hline $\mathrm{TO}_{\mathrm{t}}$ & -0.169 & $-1.471^{* * *}$ & 0.151 \\
\hline $\operatorname{INF}_{\mathrm{t}}$ & 0.090 & $1.79^{* * *}$ & 0.100 \\
\hline T & & 43 & \\
\hline $\mathbf{R}^{2}$ & & 0.37 & \\
\hline F-statistic & & $0.784(p<0.63)$ & \\
\hline Log likelihood & & 2.85 & \\
\hline
\end{tabular}

*Significant at $1 \% ; * *$ Significant at 5\%; ***Significant at $10 \%$. 


\section{Results}

- Both RD\&E and RFT (North, Center and South) are strongly correlated with output and TFP growth

- Except the RFTC and TO, the rest of variables have the expected signs

- The variables RFT's are significant at a 1 per cent level for the RFTN while that of RFTC and RFTS are not statistically insignificant

- A one per cent increase in RD\&E stock and RFTCN would increase TFPG by 0.05 and 0.21 per cent, respectively

- The rise of $1 \%$ in investments in roads resulted in an average increase of $0.09 \%$ in TFP, at $10 \%$ of significance. 


\section{Discussions}

- Even when TO is negatively affecting TFP growth, more analysis should be undertaken to identify the distribution of the revenues generated by this trade

- Especially if we know that many foreign direct agricultural investments have been done in Tunisia during the last two centuries...

- A focus should be made on the rain fed agriculture since even with the extension of the irrigated areas, the agricultural productivity in Tunisia remains very variable from one year to another 
Conclusions

- RD\&E expenditure and rainfall are important for the growth of agricultural productivity

- Climate variability has a heavier negative effect on the TFP, compared to the low positive effect of RD\&E expenditures

- $\quad$ keeping the same RD\&E strategy, these is much evidence that the TFP of the agricultural sector in Tunisia will be negatively affected by climate variability which expected to further increase with climate change 


\section{Implications}

- $\quad$ Proper utilization of rainfall is necessary; mainly in the north part of the country where rain is relatively abundant and yields of different rain fed crops have a large potential to further increase

- Technical packages and farmers' skills are to be enhanced

- Increasing and prioritization of RD\&E expenditures in the agricultural sector are also necessary to redress the expected deteriorating climate conditions (Public-Private Partnership)

- These investments have the potential to improve the long-run prospects for productivity growth 


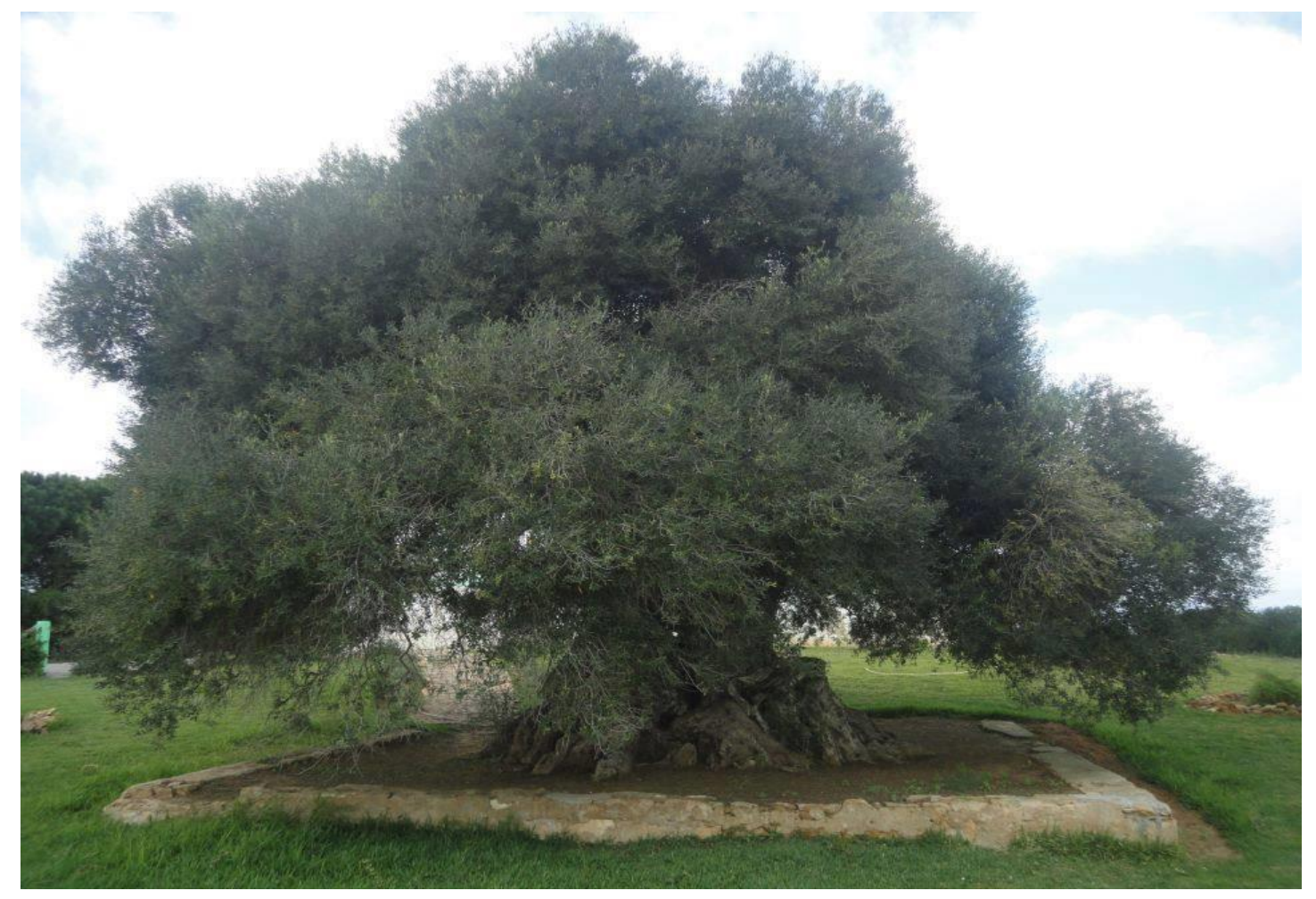

Thank you, any questions? 